\title{
Performance Analysis of Rooftop Solar Plants in CVR College of Engineering: A Case Study
}

\author{
P. Rajesh Kumar' and Ch. Lokeshwar Reddy ${ }^{2}$ \\ 'CVR College of Engineering/ EEE Department, Hyderabad, India. \\ Email: p.rajeshkumar@cvr.ac.in \\ ${ }^{2}$ CVR College of Engineering/ EEE Department, Hyderabad, India \\ Email: reddy.lokeshwar@gmail.com
}

\begin{abstract}
The growing electrical energy demand in developing countries like India has triggered the scientists and engineers to think of new and innovative methods in the field of renewable energy sources especially solar energy. Grid connected PV systems have become the best alternative to bulk electrical power consumers like industries and other institutions. In this paper $280 \mathrm{kWp}$ Photovoltaic Grid Connected Power Plant commissioned at CVR College of Engineering is taken for research study. This Plant uses three different mechanisms to trap the Solar energy from the Sun, namely Seasonal tilting, Single axis tracking and Single axis Polar tracking. The twelve months of a year is segmented into two time frames viz. from September to March and other from April to August. In one time frame Single Axis Polar Tracking Power Plant is giving better performance whereas in other time frame Single axis tracking Power Plant is giving better output. Further research and investigation has to be done on these results to predict the performance of the plants in these two time frames and exact reasons for these outputs.
\end{abstract}

Index Terms - Grid Connected Solar Power Plant, Polar Tracking, Single Axis Tracking, Solar Radiation, Seasonal Tilt.

\section{INTRODUCTION}

Increasing electrical energy demand and high cost fossil fuels, global warming and environmental issues increase the importance of the use of clean and renewable energy sources. There are many types of naturally available sources of energy which can be replenished over a period of time. Solar energy, wind energy and biomass energy are few to mention as examples. All these renewable sources of energy have the capability of converting the naturally available sources of energy into electrical Energy [1].

Today's daily Electrical energy needs, cost of fossil fuels and effect of greenhouse gases on environment forces the industrial and other institutions to seek for new ways to generate their own electrical demand using renewable energy.

India has an abundance of solar radiation, with the peninsula receiving more than 300 sunny days as an average in a year. Due to its proximity to the equator, India receives abundant sunlight throughout the year [2]. For countries like India, Solar energy became the best alternative and viable renewable energy to fulfill the electrical energy requirements of majority of the people living in both urban and rural areas for variety of applications.
The most familiar way to generate electricity from solar energy is to use photovoltaic cells, which are made up of silicon that converts the solar energy falling on them directly into electrical energy. This is a direct energy conversion which involves photo-electric effect. Large scale applications of photovoltaic for power generation, either on the rooftops of houses or in large fields connected to provide clean, safe and strategically sound alternatives for production of electrical power generation [3].

Solar PV solution has the potential to transform the lives of many people, who rely on highly subsidized kerosene oil and other fossil fuels, primarily to light up their homes. Renewable energy source is a practical solution to address the persistent demand supply gap in the power industry.

\section{Types Of Photo Voltaic System}

On the basis of working operation, PV systems can operate in four basic forms [4].

\section{A. Grid Connected PV Systems}

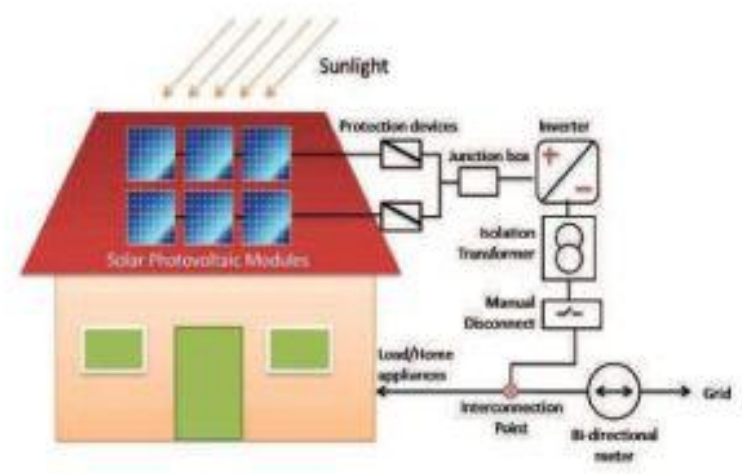

Figure 1. Block diagram of Grid connected PV Plant with net metering

The "Fig. 1," shows the block diagram of Grid connected PV plant with net metering. These systems are connected to a broader electrical network called Grid. The PV System is connected to the utility grid using a high quality sine wave inverters, which converts DC power generated from the solar array into AC power. During the day, the solar electricity generated by the system is either used immediately for local loads or export to electricity supply companies. In the evening, when the PV System is unable to 
generate electrical power, electricity can be imported from the grid [5].

\section{B. Standalone Systems}

The "Fig. 2," shows the block diagram of standalone PV system. PV systems not connected to the electric utility grid are known as Off Grid PV Systems and also called standalone systems. Direct systems use the PV power immediately as it is produced, while battery storage systems can store energy to be used at a later time, either at night or during cloudy weather. These systems are used in isolation of electrical grid, and maybe used to power local loads.

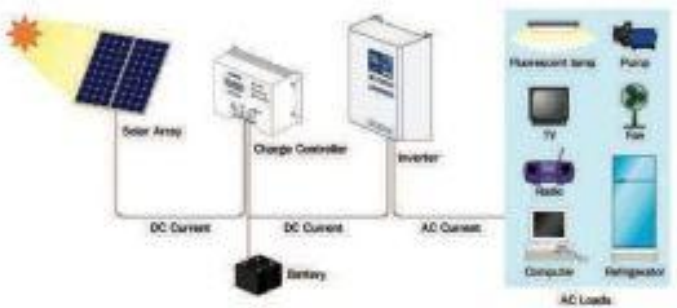

Figure 2. Block diagram of standalone PV system

\section{Hybrid System}

The "Fig. 3," shows the block diagram of Hybrid PV system. A hybrid system combines PV with other forms of power generation, usually a diesel generator. Bio gas is also used. The other form of power generation is usually a type which is able to modulate power output as a function of demand. However, more than one form of renewable energy may be used e.g. Wind and Solar. The Photo Voltaic Power generation serves to reduce the consumption of fossil fuel.

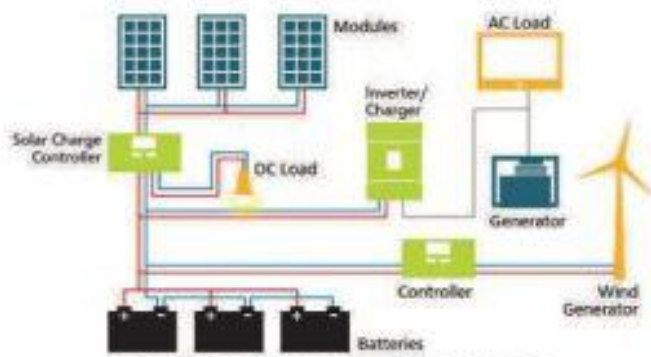

Figure 3. Block diagram of Hybrid PV System

\section{Grid Tied with Battery Backup PV system}

The "Fig. 4," shows the block diagram of Grid tied with Battery Backup PV system. Solar energy stored in batteries can be used at night time. Using net metering, un used solar power can be sold back to the grid. With this system consumer will have power even if grid fails [6].

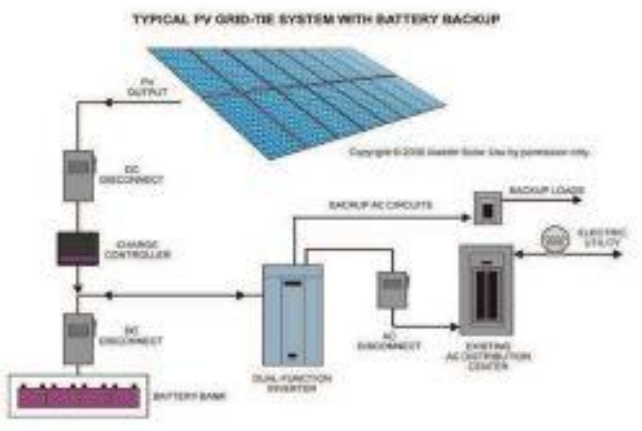

Figure 4. Block diagram of Grid tied with Battery Backup PV System

\section{SITE DETAILS}

The grid connected solar power plant under this research study is located on roof top of CVR College of Engineering. This college is located in vastunagar, Mangalpalli village, which comes under Ibrahimpatnam district located in Telangana state in India.

\section{Project location} Location: Hyderabad Latitude: $17.20^{\circ} \mathrm{N}$ Longitude: $78.60^{\circ} \mathrm{E}$ Elevation: $545.00 \mathrm{~m}$

\section{Climate data location Location: Hyderabad Latitude: $17.45^{\circ} \mathrm{N}$ \\ Longitude: $78.47^{\circ} \mathrm{E}$ \\ Elevation: $545.00 \mathrm{~m}$}

The solar radiation data of project location is not available at exact project location. So the solar radiation data and other climate conditions at project location are assumed to be the same that is available at the nearest climate data location given by NASA [7]. Climate data of the location as per information provided by NASA are tabulated in Table 1 below.

TABLE I.

MONTH WISE AVERAGE GLOBAL HORIZONTAL RADIATION, AMBIENT TEMPERATURE, GLOBAL INCIDENT IN COLL.PLANE AND EFFECTIVE

\begin{tabular}{|l|l|l|l|l|}
\hline \multicolumn{1}{|c}{ Month } & $\begin{array}{l}\text { GlobHor } \\
\mathbf{k W h} / \mathbf{m}^{2}\end{array}$ & $\begin{array}{c}\text { T Amb } \\
\mathbf{0} \mathbf{C}\end{array}$ & $\begin{array}{l}\text { Globalnc } \\
\mathbf{k W h} / \mathbf{m}^{2}\end{array}$ & $\begin{array}{l}\text { GlobEff } \\
\mathbf{k W h} / \mathbf{m}^{2}\end{array}$ \\
\hline January & 158.4 & 23.00 & 199.1 & 194.3 \\
\hline February & 164.6 & 25.70 & 193.5 & 188.7 \\
\hline March & 203.9 & 29.10 & 218.4 & 212.6 \\
\hline April & 202.3 & 31.40 & 196.8 & 190.5 \\
\hline May & 206.1 & 32.60 & 187.7 & 180.9 \\
\hline June & 161.2 & 29.20 & 143.9 & 138.3 \\
\hline July & 13.0 & 26.80 & 126.0 & 121.2 \\
\hline August & 146.4 & 25.70 & 138.6 & 133.6 \\
\hline September & 162.6 & 26.10 & 167.1 & 161.8 \\
\hline October & 166.6 & 25.50 & 186.1 & 181.0 \\
\hline November & 152.6 & 24.00 & 187.5 & 182.8 \\
\hline December & 154.0 & 22.10 & 198.8 & 194.1 \\
\hline Year & 2017.8 & 26.77 & 2143.3 & 2079.6 \\
\hline
\end{tabular}




\section{Plant Description}

The Grid connected solar power plant located on Roof top of CVR College of engineering has total installed capacity of $280 \mathrm{~kW}_{\mathrm{p}}$. This $280 \mathrm{kWp}$ capacity solar power plant is further decentralized into 5 sub plants for proper operational and maintenance.

The Electrical Energy output of the Solar Power Plant is directly proportional to amount of Solar radiation that solar Array will receive at any point of time. More the amount of solar energy received by the solar array, more the electrical energy output. vice-versa.

So the new classification of Solar power plants based on the way how the solar array receives the solar energy from the sun can be categorized into three types

(A) Seasonal Tilt/Manual tilte

(B) Single-Axis Tracking

(C) Single- Axis Polar Tracking

The complete capacity of solar plant on each block of CVR College of Engineering is tabulated in Table II including the dates on which each plant operation started to their full capacity.

Out of $280 \mathrm{kWp}$ of installed capacity $120 \mathrm{kWp}$ on rooftop of EEE Block and $20 \mathrm{kWp}$ on rooftop of Library block makes use of Seasonal tilt mechanism. $80 \mathrm{kWp}$ on Main block and $60 \mathrm{kWp}$ on CSE block uses tracking mechanism to extract the Solar energy from the sun. Overall, $140 \mathrm{kWp}$ solar plant uses seasonal tilt mechanism and remaining 140 $\mathrm{kWp}$ solar plant uses tracking mechanism for electrical power generation [8].

TABLE II.

DETAIIS OF NAME OF SUB PLANTS, THEIR CAPACTIES AND DATE OF COMMENCEMENT OF PLANT

\begin{tabular}{|l|c|c|}
\hline Name of the Sub Plant & Installed Power & $\begin{array}{c}\text { Date of } \\
\text { Commencement } \\
\text { of Plant }\end{array}$ \\
\hline CVR EEE Block & $120.00 \mathrm{kWp}$ & $03-03-2014$ \\
\hline Single Axis Tracking-MB & $40.00 \mathrm{kWp}$ & $18-01-2015$ \\
\hline Library & $20.00 \mathrm{kWp}$ & $23-02-2015$ \\
\hline Polar Tracking -MB & $40.00 \mathrm{kWp}$ & $11-03-2015$ \\
\hline CVR CS Block & $60.00 \mathrm{kWp}$ & $22-10-2015$ \\
\hline Overall Plant Capacity & $\mathbf{2 8 0 . 0 0 k W p}$ & $\ldots$ \\
\hline
\end{tabular}

\section{A. Seasonal Tilt/Manual tilt}

Placing the modules facing the south with some tilt with respect to horizontal roof, on which panels are mounted. In this method for every month we need to adjust the tilt of solar modules. This is called seasonal tilting but changing the position of solar panels every month is quite difficult, we try to restrict the change the tilt of modules for every season.

\section{B. Single-Axis Tracking}

In single axis trackers, a long horizontal tube is supported on bearings mounted upon pylons or frames. The axis of the tube is on a north-south line. Panels are mounted upon the tube, and the tube will rotate on its axis to track the apparent motion of the sun through the day.
In these methods panels are oriented in East-West direction. The moment sun rises in the East solar panels automatically face east direction' It will be horizontal when LST is 12:00 noon and will face the West in the evening. This method of tracking the sun is called Single-Axis tracking

\section{Single-Axis Polar Tracking}

In Single-Axis tracking, the modules are mounted flat at 0 degrees with respect to horizontal. While in Single Axis Polar Tracking the modules are installed at a certain tilt (10 degrees) with respect to horizontal axis. It works on same principle as Single- Axis Tracking, keeping the axis of tube horizontal in north-south line and rotates the solar modules from the east to the west throughout the day. This method of tracking is named as Single axis Polar tracking. These trackers are usually suitable in high latitude locations

Main components of Grid connected PV Plant are [9]

1. Solar Panels/Solar Modules/ Solar Array

2. String inverter

3. DC Cables

4. AC Cables

5. Junction Boxes

6. Net meter (bi-directional Meter)

Solar panels/ Modules/Array will collect the energy from the sun in the form of solar radiation. this solar radiation is converted into DC electrical energy by solar Array. This DC Electrical energy is given as input to grid interactive String inverters with the help of DC Cables. These string inverters convert DC electrical Energy into AC electrical energy. The output $\mathrm{AC}$ electrical energy of inverter will be sent to local junction box with the help of AC Cables. From the junction box depending upon local load requirement the $\mathrm{AC}$ power will be either pumped to electrical grid or utilized for local energy requirements. There will be a bi- directional energy meter is installed at incoming transformer from the external grid [10]. Generated Solar Electric Power is synchronized at $11 \mathrm{kV}$ bus. This Net meter increment the energy units when ever local load requirement is more than $\mathrm{AC}$ electrical energy output of Solar Plant and vice-versa.

The below "Fig. 5," shows the exact on site photograph of $40-\mathrm{kWp}$ Single axis tracking power plant commissioned on Main block of CVR College of Engineering. It is evident from photograph that Solar array at 9:30 A.M. facing towards the east.

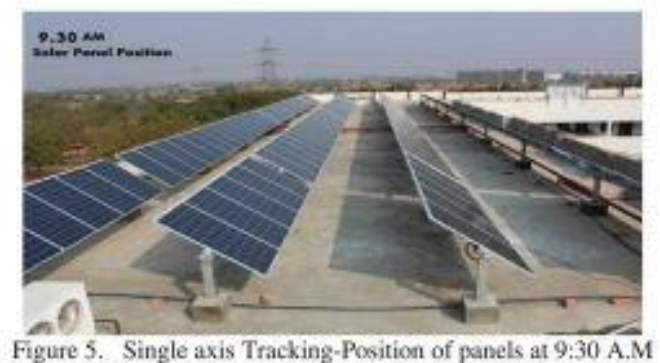


Similarly, "Fig. 6 and 7," shows the position of solar panels at 3:00 P.M and 12:30 P.M respectively. As mentioned earlier Single axis tracking plant always follows the position of the sun in the sky throughout the day to collect the maximum energy from the sun.

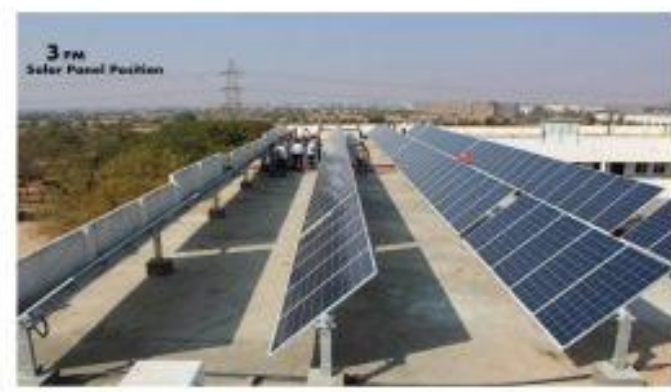

Figure 6. Single axis Tracking-Position of panels at 3:00 P.M

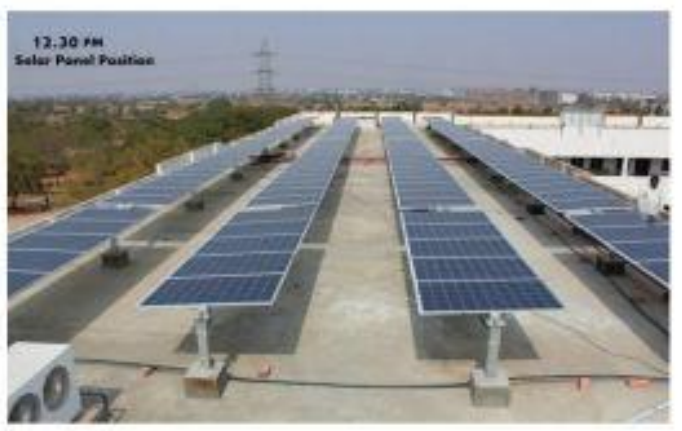

Figure 7. Single axis Tracking-Position of panels at 12:30 P.M

The "Fig.8," shows the 3-D view of Single axis Polar tracking power plant.

Solar Panels and string inverters are the heart of grid connected solar power plant. Multi crystalline Solar panels are used in the solar array. Each Solar panel has maximum electrical output power of 250 Watt at 1000 W/Sq.m Solar radiation. Panels are manufactured by Kohima Energy Private Limited. Model Number of Solar panel is KE-60M250. These Solar panels have 25 years' manufacturer guarantee.

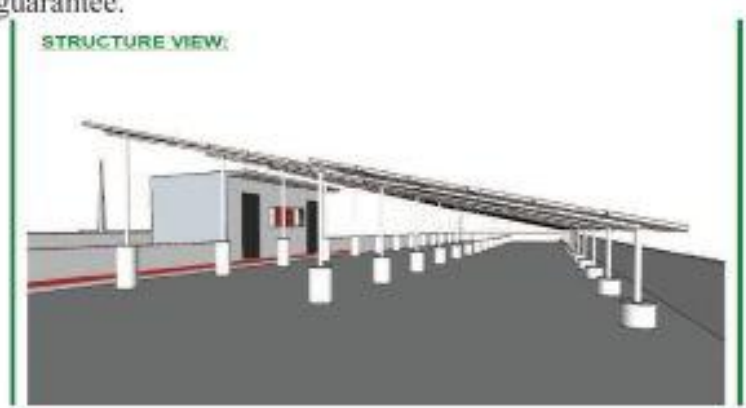

Figure 8. 3-D view of Single axis polar tracking plant

The inverters used in this power plant are $20-\mathrm{kW}$ Refusol grid interactive string inverter. Model number is REFUsol $008 \mathrm{~K}-020 \mathrm{~K}$. This is a three phase sine wave inverter as per IP 65 standards with $98.2 \%$ maximum efficiency.

\section{RESULTS AND DISCUSSIONS}

The details of energy output of each and every string inverter and sub plant can be monitored online by web interface AE Sitelink [11]. Total energy outputs of Single axis tracking power plant are compared with Polar tracking power plant from April'15 to October'16.

The energy outputs of these two Power plants are monitored in the above mentioned specified period and are tabulated in Table III. The "Fig. 9," shows the graphical representation of energy outputs of single axis tracking power plant with single axis Polar Tracking Power plant over a monitored period April'15 to October'16. After observing the data, we can divide the time frame taken into two slots. One is from April to September and another one is from October to March

From the "Fig 9," and data from Table III, we can conclude that during the period from April to August the energy generated by Single axis tracking power plant is more than Single axis polar plant. Whereas from September to March it is evident that output of Single Axis Polar tracking power plant is more than Single axis tracking plant.

As performance of both plants is varying between these two time frames, one random date is chosen from each time frame. May $22^{\text {nd }} 2016$ is selected for first time frame and Oetober $14^{\text {th }} 2016$ is chosen for other time frame.

The "Fig. 10, 11 and 12," show the energy outputs of each $20 \mathrm{~kW}$ String Inverter which are connected to Single axis Polar Plant, Single axis tracking Plant and Seasonal tilt Power Plants respectively. From figures one can conclude that on $14^{\text {th }}$ October 2016 the performance of Single axis Polar Plant is best among three types of Solar PV Power Plants [12].

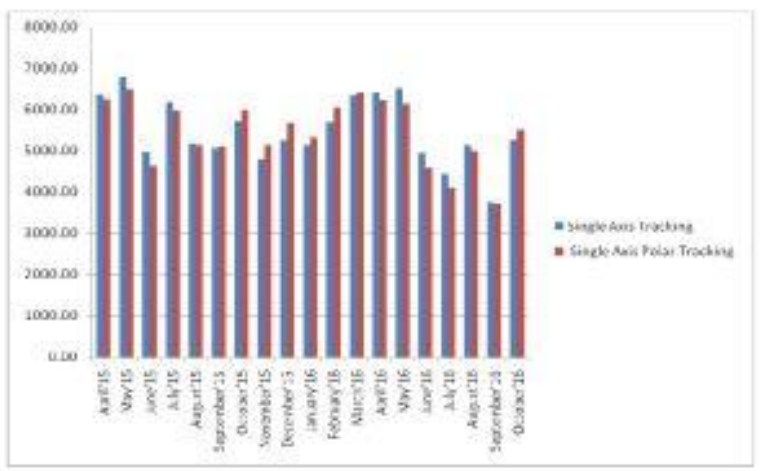

Figure 9. Energy outputs of single axis tracking power plant with single axis Polar Tracking Power plant over a monitored period 
TABLE III.

MONTH WISE ELECTRICAL ENERGY OUTPUTS OF TRACKING AND POLAR TRACKING POWER PLANTS AND THEIR PERCENTAGE VARIATION

\begin{tabular}{|l|r|r|r|c|}
\hline Month-year & $\begin{array}{c}\text { Single } \\
\text { Axis } \\
\text { Trackin } \\
\mathrm{g}\end{array}$ & $\begin{array}{c}\text { Single Axis } \\
\text { Polar } \\
\text { Tracking }\end{array}$ & $\begin{array}{c}\text { Net } \\
\text { Differe } \\
\text { nec }\end{array}$ & $\begin{array}{c}\% \\
\text { Percentage } \\
\text { Variation }\end{array}$ \\
\hline Apri'15 & 6362.30 & 6251.90 & 110.40 & 1.74 \\
\hline May'15 & 6782.40 & 6486.50 & 295.90 & 4.36 \\
\hline June'15 & 4960.30 & 4640.60 & 319.70 & 6.45 \\
\hline July'15 & 6188.20 & 5964.70 & 223.50 & 3.61 \\
\hline August'15 & 5174.10 & 5149.20 & 24.90 & 0.48 \\
\hline September'15 & 5061.90 & 5101.40 & -39.50 & -0.78 \\
\hline October'15 & 5726.20 & 6005.50 & -279.30 & -4.88 \\
\hline November'15 & 4785.20 & 5139.90 & -354.70 & -7.41 \\
\hline December'15 & 5248.00 & 5677.50 & -429.50 & -8.18 \\
\hline January'16 & 5148.60 & 5335.00 & -186.40 & -3.62 \\
\hline February'16 & 5681.80 & 6045.40 & -363.60 & -6.40 \\
\hline March'16 & 6341.00 & 6425.10 & -84.10 & -1.33 \\
\hline April'16 & 6403.60 & 6222.50 & 181.10 & 2.83 \\
\hline May'16 & 6515.00 & 6137.80 & 377.20 & 5.79 \\
\hline June'16 & 4956.20 & 4585.70 & 370.50 & 3.48 \\
\hline July'16 & 4435.30 & 4106.00 & 329.30 & 3.42 \\
\hline August'16 & 5148.60 & 5003.00 & 145.60 & 2.83 \\
\hline September'16 & 3757.20 & 3724.50 & 32.70 & 0.87 \\
\hline October'16 & 5278.40 & 5505.90 & -227.50 & -4.31 \\
\hline
\end{tabular}

Similarly, the "Fig. 13,14 and 15," show the energy outputs of each 20kW String Inverter which are connected to Single axis tracking plant, Single axis Polar Plant and Seasonal tilt Power Plants respectively. It is evident from charts that on $22^{\text {sd }}$ May 2016, performance of Single axis tracking plant is best among three types of Solar PV Power Plants [12].

After comparing the outputs of Single axis tracking Power Plant and Single axis Polar Plant, we can conclude that from September to March Polar tracking Power Plant is giving more output. Whereas from April to August Single Axis tracking is giving more output [12].

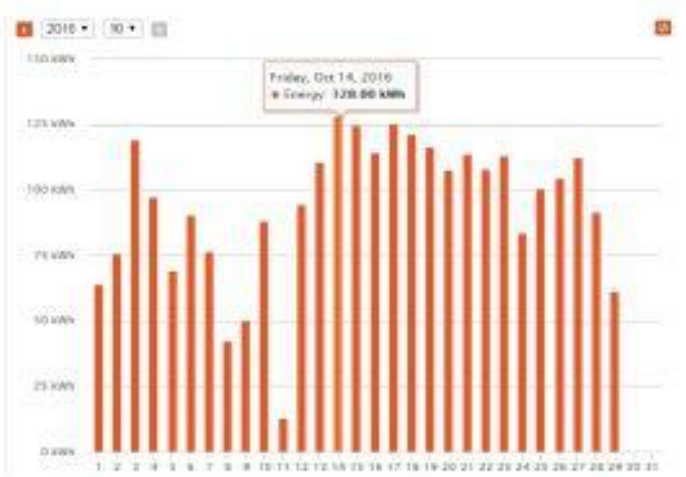

Figure 10. Energy generated by Single Axis Polar tracking-20kW String Inverter output on $14^{\text {th }}$ October'16

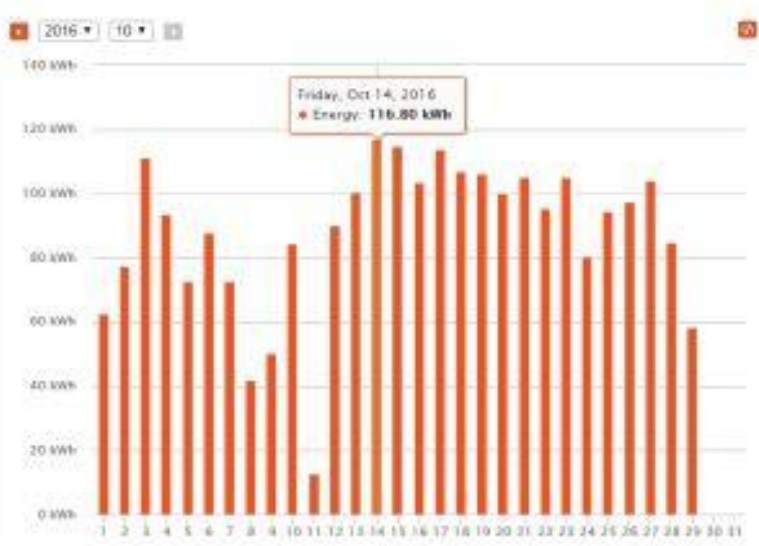

Figure 11. Energy generated by Single Axis Tracking-20kW String Inverter output on $14^{\text {th }}$ October' 16

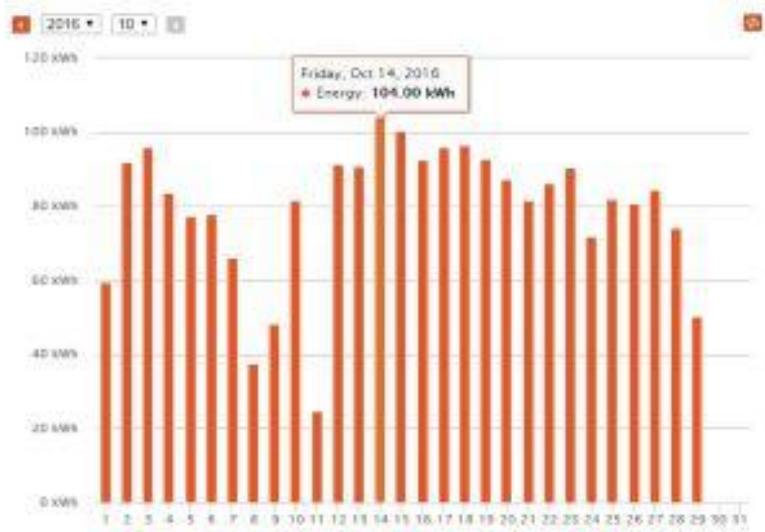

Figure 12. Energy generated by Seasonal tilt $-20 \mathrm{~kW}$ String Inverter output on $14^{\text {th }}$ October ' 16

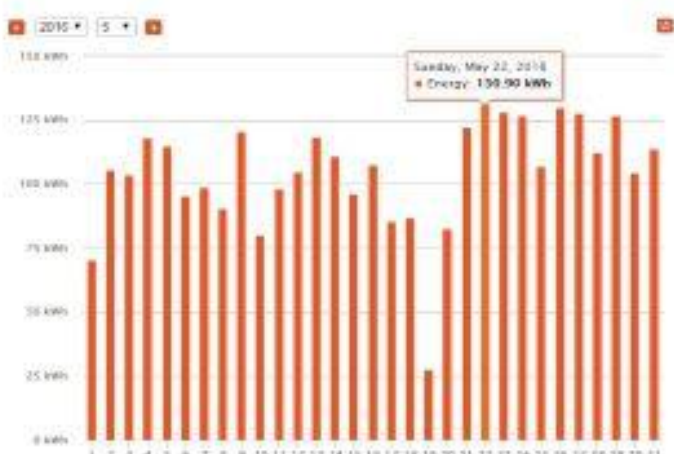

Figure 13. Energy generated by Single axis tracking-20kW String Inverter output on $22^{\text {od }}$ May' 16 


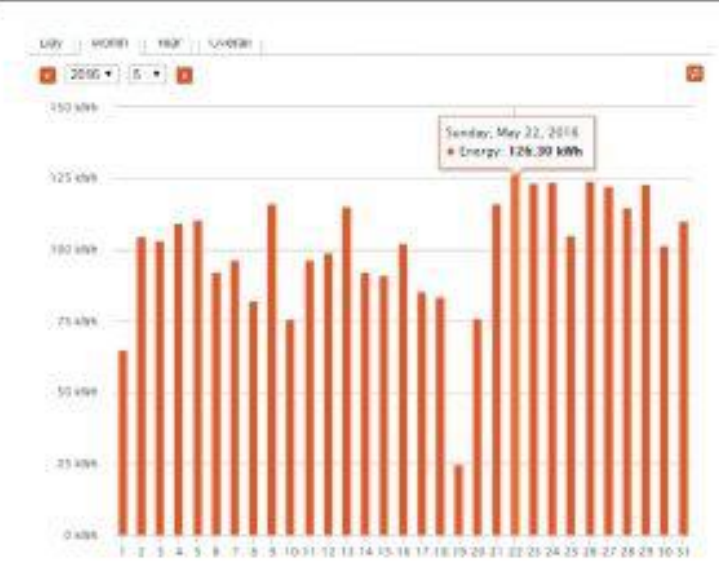

Figure 14. Energy generated by Single Axis Polar tracking-20kW String Inverter oulput on $22^{\text {nd }}$ May' 16

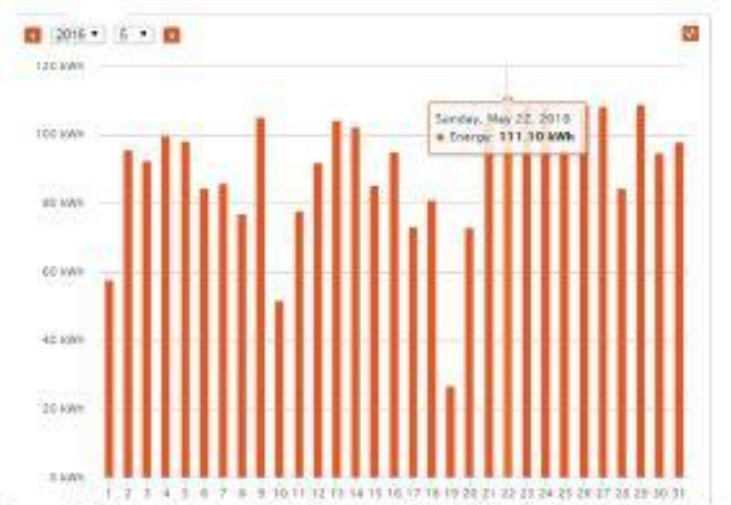

Figure 15. Energy generated by Seasonal tilt $-20 \mathrm{~kW}$ String Inverter output on $22^{\text {sd }}$ May' 16

\section{Conclusions}

In this paper, a $280 \mathrm{kWp}$ Grid Connected Photo Voltaic Power Plant commissioned at CVR College of Engineering is taken for research study. The electrical energy outputs of different Solar PV Power Plants are studied and analyzed.

The twelve months' time in an year is divided into two time frames viz. From September to March and other from April to August. A random date of $14^{\text {th }}$ October 2016 is chosen in first time slot. On this day Single Axis polar tracking gives better performance among the three. A random date of $22^{\text {nd }}$ May 2016 is taken in second time frame. On this date Single Axis tracking gives better performance among the three.

Further research has to be done on these results for better analysis and exact reasons to investigate performance of the plant in these two different time frames. Since these results obtained are only for 19 Months, at least two complete cycles will give us better idea because weather and climate conditions may not be the same every year in the monitored time frame.

\section{REFERENCES}

[1] R. E. P. N. for the 21 st Century, "Renewables 2012 global status report," tech. rep.,

[2] India Solar Resource Maps (2010): http:/www.mnre.gov.in/centers/about-sec- 2/solarresources/, Ministry of New and Renewable Energy Govt. of India

[3] Sukhatme and Nayak, Solar Energy: Principles of Thermal Collection and Storage, Tata McGraw.Hill, 2008

[4] J. A. VENTRE et al., Photovoltaic systems engineering. CRC press, 2004.

[5] L.M. Ayompe, A. Duffya, S.J. McCormack, M. Conlon, "Measured performance of a $1.72 \mathrm{~kW}$ rooftop grid connected photovoltaic system in Ireland," Volume 52. Issue 2. Februar 2011, Page 816-825.

[6] M. Sidrach-de-Cardona, LI. Mora Lopez, "Performance analysis of a grid-connected photovoltaic system," Energy 24 (1999); 93-102.

[7] Solar Radiant Energy over India. (2009) ed. Ajit P. Tyagi, India Metrological Department, Ministry of Earth Sciences, Govt. of India

[8] P. B, Miro Zeman, "Photovoltaic systems reader." University Lecture, 2013.

[9] IEC, "Photovoltaic system performance monitoringguidelines for measurement, data exchange and analysis," IEC standard 61724, Geneva, Switzerland; 1998

[10] M. Zeman, "Photovoltaic basics syllabus." University Lecture, 2011.

[I1] Khatib, T., Sopian, K., Kazem, H. Actual performance and characteristic of a grid connected photovoltaic power system in the tropics: A short term evaluation. Energy Conversion and Management. 71(2013): 115-119.

[12] Deepthi.S, Ponni,A, Ranjitha.R, R Dhanabal, "Comparison of Efficiencies of Single-Axis Tracking System and Dual-Axis Tracking System with Fixed Mount", International Journal of Engineering Science and Innovative Technology (IJESIT), Volume 2, Issue 2, March 2013. 